\title{
BRITISH ARMY CHAPLAINS AND CAPITAL COURTS-MARTIAL IN THE FIRST WORLD WAR
}

\author{
by MICHAEL SNAPE
}

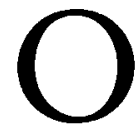

F all the dark legends which have arisen out of the British experience of the First World War, perhaps none is more compelling than the fate of more than three hundred British, Dominion and Colonial soldiers who were tried and executed for military offences during the course of the conflict. Controversial at the time, these executions were the subject of much debate and official scrutiny in the inter-war period and, even today, the subject continues to have a bitter and painful resonance. Led by the Shot at Dawn Campaign, ${ }^{1}$ pressure for the rehabilitation of these men continues and the case for a millennium pardon was marked in June $200 \mathrm{I}$ by the opening of an emotive memorial to them at the National Memorial Arboretum near Lichfield. However, this paper is not concerned with the justice of the proceedings which led to the deaths of these men. ${ }^{2}$ Whether due legal process was followed or whether those executed were suffering from shell shock are difficult and probably unanswerable questions which I will leave to legal and to military historians. Instead of investigating the circumstances of the condemned, this paper turns the spotlight onto the circumstances and attitudes of men whose presence at military executions was as inevitable as that of the prisoner or the firing squad; namely, the commissioned chaplains of the British army.

1 Cf. the website www.shotatdawn.org.uk for more information (consulted 6 December 2002). For an appraisal of the Shot at Dawn campaign, see B. Bond, The Unquiet Western Front: Britain's Role in Literature and History (Cambridge, 2002), 82-4.

2 For more general discussions of the military and legal issues surrounding these executions see Cathryn Corns and John Hughes-Wilson, Blindfold and Alone: British Military Executions in the Great War (London, 200 I); William Moore, The Thin Yellow Line (London, 1974, repr. 1999); Anthony Babington, For the Sake of Example: Capital Courts-Martial $1914-1920$ (London, 1983; 2nd edn, 1993); Julian Putkowski and Julian Sykes, Shot at Daun: Executions in World War One by Authority of the British Army Act (Barnsley, 1989; 2nd edn, London, 1992); Leonard Sellers, For God's Sake Shoot Straight: the Story of the Court Martial and Execution of Temporary Sub-Lieutenant Edwin Leopold Arthur Dyett, Nelson Battalion, 63rd (RN) Division during the First World War (London, 1995); Gerard Oram, Worthless Men: Race, Eugenics and the Death Penaly in the British Army during the First World War (London, 1998). 
Although generally overlooked by historians, one of the many ways in which British army chaplains throughout the First World War demonstrated their identification with the army as an institution and with the aspirations and objectives of its commanders was in their largely uncritical attitude towards the system of military justice which led to nearly three hundred British soldiers being 'shot at dawn'. In addition to indicating tacit approval of extreme means of maintaining discipline, this attitude also reflected the attitude of many if not most British churchmen towards capital punishment per se. In a survey of ecclesiastical opinion on the death penalty which was carried out by the Society for the Abolition of Capital Punishment in I900, all episcopal respondents supported the right of the state to inflict the ultimate sanction, a position which was justified in the case of murderers by reference to Gen. 9: $6 .{ }^{3}$ However, only fifteen of the 291 soldiers from British units who were executed between 4 August 1914 and 31 March 1920 were executed for murder; the great majority (some 240) being shot either wholly or in part for the military offence of desertion, the rest being executed for cowardice, sleeping at their post, mutiny or striking a superior officer. ${ }^{4}$ The qualitative difference between wilful murder and offences which could lead to the death penalty under the Army Act was obvious to many contemporaries. So too, it might be added, was the rate at which these executions were carried out, their number exceeding the total of executions for murder in England and Wales for the twenty-year period $1900-19 .{ }^{5}$ The fact that the clergy either openly or tacitly endorsed the death penalty in both cases naturally invited criticism. As one ex-officer wrote of Private James Crozier of the gth Royal Irish Rifles, who was executed for desertion in February I9I6,

In the eyes of God, of course, he had committed no specific sin demanding repentance; therefore the Chaplain's task was easy ... why the culprit had to make his peace with God when the only trouble he had at the time was with the Commander-in-Chief of the British Armies in France, I do not know. ${ }^{6}$

3 Harry Potter, Hanging in Judgment: Religion and the Death Penalty in England (London, 1993), 107.

4 The War Office, Statistics of the Military Effort of the British Empire during the Great War 1914-1920 (London, 1992), 649.

5 Royal Commission on Capital Punishment 1949-53, Report: Presented to Parliament by Command of Her Majesty, September 1953, ed. Ernest Arthur Gowers (London, 1953, 2nd edn., I 965), Appendix 3.

6 F. P. Crozier, The Men I Killed (London, 1937, repr. Bath, 1969), $51,219$. 
For reasons such as these, the infliction of the death penalty for offences under the Army Act provoked a large measure of controversy among the ordinary soldiers of the British Expeditionary Force (BEF). According to one Roman Catholic chaplain, many soldiers were 'altogether opposed to the death sentence', these feelings being especially strong among the volunteers of Lord Kitchener's vast New Army. ${ }^{7}$ In addition to stoking debate, the death penalty also caused considerable resentment in those units which were affected by its application. In part, this could be the consequence of a certain sympathy for the condemned, especially in cases where the proceedings of their court-martial were thought to be unfair. This was certainly a factor in the reaction of the 2 nd Scots Guards to the execution of Private Isaac Reid, who was shot at Laventie in April I915. In the wake of his death, 'all sentimentalised the poor private soldier and made a hero out of him', Reid being rumoured to have been the victim of a malevolent sergeant-major, an inept personal defence and a nervous disorder which the army would later officially recognize as shell shock. ${ }^{8}$

However, this resentment was also a product of the element of collective punishment which executions were known to symbolize. Given the mechanisms whereby the sentences of courts-martial were confirmed (death sentences being passed up the chain of command until they were confirmed or commuted by the Commander-in-Chief whose decision was then relayed downwards for promulgation), ${ }^{9}$ a significant factor in determining whether a man should be shot was the perceived condition of his unit. Indeed, it was not unknown for commanding officers to lobby for the confirmation of death sentences because of problems of discipline and morale among their own men. ${ }^{10}$

As the duke of Wellington memorably put it, military punishments were essentially 'for the sake of example', with the punishment of offenders being useful 'only in the cases where the prevalence of any crime, or the evils resulting from it, are likely to be injurious to the public interest'." Consequently, the exemplary nature of military executions in the First World War sometimes involved troops being

7 R. H. J. Steuart, March, Kind Comrade (London, 1931 ), 94-5.

8 S. Graham, A Private in the Guards (London, 1919; 2nd edn, 1928), 159-6I; M. Brown, Tommy Goes To War (London, 1986), I 28.

9 Corns and Hughes-Wilson, Blindfold and Alone, 85-104; J. Peaty, 'Capital CourtsMartial during the Great War', in Brian Bond et al., eds, Look to Your Front': Studies in the First World War by The British Commission for Military History (Staplehurst, 1999), 89-104, 92, 98.

10 Babington, For the Sake of Example, 59-60; Crozier, The Men I Killed, so.

11 Babington, For the Sake of Example, vi. 
paraded to witness the fate of the condemned. ${ }^{12}$ Even when executions were of a more private nature, firing parties were usually drawn from the prisoner's own unit, with details numbering as many as eighteen men. ${ }^{13}$ In any event, news of these executions was widely and purposefully circulated in the form of the army's General Routine Orders 'to encourage others not to commit the same offence.'. ${ }^{4}$

Despite the public manner in which Private Reid met his end, the whole of the 2nd Scots Guards being paraded to behold the salutary spectacle, ${ }^{15}$ the number of British soldiers who actually witnessed a military execution was, relatively speaking, extremely small. In fact, the 29I British soldiers who died in this way represented a mere 0.005 per cent of the 5.7 million men who served in the British army during the First World War. If the number of soldiers who witnessed their fate was inevitably small, the same factors also conspired to ensure that the chances of an individual army chaplain being called upon to minister to a man about to die in this manner were remote to say the least. In fact, the chaplains who ministered to those who were actually 'shot at dawn' comprised only a tiny fraction of the total number of chaplains who served in the army between I9I4 and 1918. Whereas 291 soldiers from British units were executed during the course of the war, there were nearly 3,500 chaplains serving with the British army by November I9I 8 , with many hundreds more having served twelve-month or even shorter contracts since the beginning of the war.

If the number of wartime chaplains therefore vastly exceeded the number of British executions under the Army Act, a padre's chances of being called upon to prepare a man to die in this fashion were further reduced by three other factors. Firstly, although 2,690 death sentences were passed on British soldiers by courts-martial between 4 August I9I4 and 31 March 1920 , the overwhelming majority - over 89 per cent in fact - were commuted at the eleventh hour. ${ }^{16}$ Under these circumstances, the number of chaplains who ministered to men about to suffer the extreme penalty was greatly exceeded by those who visited prisoners whose sentences were ultimately commuted. Secondly, there was a marked tendency for this difficult ministry to devolve upon more experienced chaplains. Julian Bickersteth, for example, attended two

12 lbid., 59-60.

13 Ibid., 57-8.

14 Corns and Hughes-Wilson, Blindfold and Alone, 103.

15 Graham, A Private, 161-2.

16 War Office, Statistics, 649; Peaty, 'Capital Courts-Martial', 92. 


\section{Army Chaplains and Capital Courts-Martial}

condemned men of the 56 th (Ist London) Division in July and December 1917. Similarly, the Revd Leonard Martin Andrews, an Anglican chaplain in the 3 rd Division, attended his first prisoner in November 1916 and maintained that he also attended a second before being badly wounded at Arras in $1917 .{ }^{17}$ If only a select group of Anglican chaplains tended to assume this responsibility, the same was also true of other denominations, with several Roman Catholic padres claiming in 1919 to have prepared more than one prisoner for execution. ${ }^{18}$ Thirdly, if very few chaplains were ever likely to undertake this role, their numbers were also limited by the wishes of the condemned, for, whilst a chaplain was a stock figure at military executions, it was left to the individual prisoner to decide whether he wished to make use of his services beforehand. ${ }^{19}$ Nevertheless, despite its rarity, chaplains were aware that this summons was a definite possibility. As an eventuality that he had 'sometimes envisaged' but never expected to encounter, when Fr R. H. J. Steuart was asked by his senior divisional chaplain to attend a deserter who was to be shot the following morning, he admitted to feeling a distinct 'thrill of repugnance'.

$$
\text { * * * }
$$

For the handful of chaplains who had dealings with soldiers about to be executed, their situation was awkward to say the least. This awkwardness stemmed from their official status as part of the military hierarchy and from their conscious identification as the soldier's friend, the latter being shaped by their status as ministers of religion, by the spiritual and practical help which they rendered to the wounded and by their role as providers of entertainment and of various other creature-comforts to the troops. Indeed, the fact that chaplains were viewed as potential allies by the other ranks is demonstrated by their being occasionally called upon to act as 'prisoner's friend' at courts-martial. Significantly, instruction on how to play the part of soldier's advocate on these occasions was a feature of the curriculum of the BEF's chaplains' school which was belatedly opened at St Omer in I 917. Indeed, Michael Adler, the BEF's senior Jewish chaplain, not only acted as prisoner's friend for

17 In fact, anothet soldier of the 3 rd Division was shot in the intervening period. See Putkowski and Sykes, Shot at Dawn: Executions, I 34, 294.

18 The Bickersteth Diaries 191 4-1 91 8, ed. John Bickersteth (London, 1996), 189-94, 224-25; Catholic Soldiers by Sixty Chaplains and Many Others, ed. C. Plater (London and New York, 1919), 124-8.

19 Babington, For the Sake of Example, 58-9.

20 Steuart, March, Kind Comrade, 95-6. 
Jewish soldiers at courts-martial but also sought legal advice from Jewish lawyers who were serving in the army. ${ }^{21}$

If chaplains could find themselves uncomfortably sandwiched between the requirements of military justice and their responsibility to individual soldiers, it should also be noted that military executions highlighted the limits of the chaplain's ability to influence soldiers' morale. Undoubtedly, on the Western Front at least, the promotion of discipline and morale became central to the chaplain's brief after January I9I6. Seen from this perspective, the execution of a soldier after this date indicated that brutal coercion had had to be used where more subtle and positive means of encouraging discipline and morale had palpably failed. In this regard, it is worth noting that the execution of Private Alfred Ansted of the ${ }^{\text {th }}$ thoyal Fusiliers occurred shortly after the Revd Noel Mellish had won the first chaplain's VC of the war whilst serving with the same battalion. Clearly, Mellish's example in selflessly recovering wounded whilst under heavy fire had failed to have a salutary influence on all.

Another sobering fact from the chaplain's point of view was that those who faced the firing squad were often persistent offenders. Significantly, 91 of the 324 British, Dominion and Colonial soldiers executed under the Army Act during the First World War were already under suspended sentences from earlier courts-martial and forty of these had already had the death sentence passed upon them. ${ }^{22}$ Although some of these may have been suffering from nervous disorders, others appear to have been shady characters and even habitual criminals who had brought their delinquent habits into the army. For R. H. J. Steuart, the prisoner whom he attended on the night of Io March 1916 remained an elusive quantity. According to Steuart, Corporal C. Lewis of the I2th Highland Light Infantry was 'a native of one of the bilingual Dominions of the Empire', although between his arrest for desertion and his trial Lewis maintained that he was an American. Whether a Canadian or an American, Lewis was apprehended in civilian clothes after deserting in January 1916, just before his battalion was due to return to the trenches. Although his civilian apparel, his previous absences and

21 Imperial War Museum, Department of Documents, 77/106/1, Revd M. W. Murray, note dated 20 October 1920; M. Adler, British Jewry Book of Honour (London, 1922; repr. Aldershot, 1997), 45 .

22 War Office, Statistics, 649 . 
his capacity for dissembling certainly indicated a determined attempt to desert, Lewis told Steuart that 'his one desire, which rapidly became an obsession, was to join the French Army, in which he believed that he would find himself at home. ${ }^{23}$

If Lewis had the air of an inveterate confidence trickster, in July 1917 Julian Bickersteth was called upon to attend Private Walter Yeoman of the I/I th Royal Fusiliers, a soldier who had been imprisoned twice in civilian life and who had deserted several times since joining the army - twice before he had even left England. ${ }^{24}$ According to Bickersteth, Yeoman had been brought over to France 'under close arrest'. Within the space of weeks, he was court-martialled for desertion and sentenced to death, a sentence which was subsequently commuted. His desertion during the battle of Arras proved to be the final straw. Significantly, although Bickersteth assumed that such reluctance could only be that of a conscript, Yeoman was a volunteer who had joined the army in $1915 .{ }^{25}$

Naturally enough, chaplains had very little in common with such men. Besides being clergymen and officers (and it must be borne in mind that only three of the British soldiers executed in the First World War were officers), both Bickersteth and Martin Andrews were exceptionally brave individuals, each of them earning a Military Cross during their service on the Western Front. If they were very different in background, rank and temperament to the men whom they attended, they were also without any formal training for the role which was thrust upon them. In the pre-war civilian context, ministering to the condemned was viewed as a highly specialized role which was best left to prison chaplains or to exemplary pastors such as Bishop Edward King, who often worked for the salvation of the condemned in Lincoln gaol. $^{26}$

By the late Victorian period, the role of the clergyman in this situation was seen as being to nurture feelings of repentance on the part of the prisoner and to enable him (or her) to become reconciled to the Almighty. This process was naturally facilitated by the growing period between sentencing and execution which occurred in the aftermath of the Capital Punishment Amendment Act of 1868. Unsurprisingly, given sedulous clerical attention over a period of weeks, many prisoners

23 Steuart, March, Kind Comrade, 97-9.

24 Bickersteth Diaries, I 89-91.

25 Ibid., I 89-90; Putkowski and Sykes, Shot at Dawn: Executions, I 78.

26 Potter, Hanging in Judgment, I $12-13$. 
proved responsive to the call for repentance. ${ }^{27}$ Circumstances were rather different, however, for army chaplains, few of whom could have had any experience of ministering to the condemned in civilian life. Significantly, death sentences were very often promulgated only days or even hours before the sentence was carried out. Hence, the chaplain usually had very little time to discuss spiritual matters with the prisoner. Perhaps because of this time scale, it was the salvation of the prisoner's soul rather than the justice of his sentence which preoccupied the chaplain.

Chaplains tended to approach prisoners and to recall their experiences in the light of existing assumptions as to the role of the clergyman in relation to the condemned. Quite simply, what was required was to ensure that the prisoner died a good death. Although chaplains' accounts indicate that visiting the condemned was taken seriously, ${ }^{28}$ they also imply that this ministry became urgent only when death sentences were finally promulgated and when prisoners realized that their time had come. It is perhaps indicative of the background and temperament of some prisoners that denominational ties were very loosely felt until their death sentences were actually confirmed. As one Roman Catholic chaplain recalled, one prisoner converted to Catholicism only twelve hours prior to his execution. Although he had been visited by a Protestant chaplain prior to that point, the prisoner received conditional baptism and his First (and last) Holy Communion a matter of hours before his death. In a similar case, a prisoner who had been educated at a Catholic school only divulged his real denomination after a senior Anglican chaplain had been visiting him for a fortnight. ${ }^{29}$

Once confronted with the condemned, chaplains had to bring them to a state of readiness for the culmination of their ordeal. Although this readiness was essentially spiritual, it was not exclusively so. Bickersteth tried to give Private Yeoman rum to drink minutes before his execution. ${ }^{30}$ Moreover, on the eve of the execution of Private Ansted, Martin Andrews not only confirmed the news of his impending death to the prisoner but also brought two pills which he had been given 'to put in his tea' and 'which would make him sleep better'. ${ }^{31}$ Although Martin

27 Ibid.

28 Catholic Soldiers, 124; Bickersteth Diaries, 190.

29 Catholic Soldiers, $125-8$. For the case of a Jewish prisoner recorded as an Anglican, see Adler, British Jewry, 45 .

30 Bickersteth Diaries, 194

31 Imperial War Museum, Sound Archive, 4770/1, Canon L. Martin Andrews. 


\section{Army Chaplains and Capital Courts-Martial}

Andrews made no overt attempt to engage in a spiritual discussion with Ansted, and thus confined his role to that of confidant and companion, Julian Bickersteth was more pro-active and more successful in his dealings with Private Yeoman.

As Bickersteth recalled, the problem was stark enough: 'Time goes on. I know that he must sleep, if possible, during the hours of darkness, so my time is short. How can I reach his soul?' After failing to elicit a response by reading a passage of Scripture, Bickersteth's suggestion that Yeoman choose a hymn for him to read from an army prayer book met with the proposal that they should sing 'Rock of Ages' together. Seizing on 'the straw' which had presented itself, in three hours which testified to the power of Sunday schools and hymnody in shaping the religious outlook even of an ex-convict from the East End of London, Bickersteth and Yeoman sang hymn after hymn from two different hymn books, the prisoner declining to sing the same hymn twice, whilst failing to appreciate the pathos of such hymns as 'Abide with me' and 'God be with us till we meet again'. As dawn broke and the firing party made ready, they said the Lord's Prayer together, a prayer which Yeoman 'knew quite well and was proud of knowing'. Nevertheless, after the brief march to the place of execution, it was to hymnody again that Yeoman turned for solace. After Yeoman was handcuffed, blindfolded and tied to the stake, Bickersteth whispered in his ear, 'Safe in the arms of Jesus', to which Yeoman 'quite clearly' replied 'Safe in the arms of Jesus' ${ }^{32}$

Thankfully, Bickersteth's next condemned prisoner proved more receptive to more conventional methods of approach. Private Henry Williams of the I/9th Royal Fusiliers was executed on 28 December 1917 for desertion, although his refusal to obey orders during a German attack the previous month seemed more akin to cowardice in the face of the enemy. ${ }^{33}$ Although already under a suspended prison sentence for desertion, Bickersteth saw in Williams only a misfortunate victim of the war. As Bickersteth wrote wearily on the day after the execution:

The last twenty-four hours have furnished me with some severe tests of physical and mental endurance. Once again it has been my duty to spend the last hours on earth with a condemned prisoner ... I have, I hope, learnt much from the simple heroism of this mere lad of nineteen, who has been out here at the Front since

32 Bickersteth Diaries, 193.

33 Putkowski and Sykes, Shot at Dawn: Executions, 224. 
19I 4.... It was my privilege to comfort and help him all I could, to hear his first and last confession, to administer the Holy Communion and to stand by his side till the very end. ${ }^{34}$

Besides strengthening Williams with the sacraments, Bickersteth received the prisoner's personal possessions for subsequent disposal and once again discovered the value of English hymnody, reading the hymn 'Just as I am without one plea!' to Williams 'just before the end..$^{35}$

Certainly, there is more than a dash of the hagiographical in Bickersteth's account of the death of Private Williams. In addition to partaking in the idealization of the victim (which, as we have seen in the case of the 2nd Scots Guards, was a common reaction among soldiers who knew the condemned), Bickersteth's account implied a spiritually purposive element in the otherwise tragic proceedings. If Williams died bathed in an aureole glow, Bickersteth was also apparently convinced that his death was not in vain. ${ }^{36}$ As a chaplain whose Anglo-Catholic sympathies grew stronger as the war progressed, Bickersteth was betraying here elements of a theology which was already explicit in Roman Catholicism.

Roman Catholic penitential theology had traditionally held that personal suffering could be offered up in atonement for one's sins, and this teaching was certainly impressed upon Catholic soldiers during the First World War. ${ }^{37}$ Seen from this perspective, the exemplary piety and patient resignation of a condemned Catholic prisoner could transcend the merely admirable and attain the heights of the spiritually sublime..$^{38}$ Indeed, there does appear to have been a marked tendency in Roman Catholic circles to see their co-religionists who were 'shot at dawn' as valuable exemplars of the Faith. Significantly, Fr Charles Plater's Catholic Soldiers, a book which was published in I9I9 and which was intended to complement the better-known Army and Religion report which was published the same year, contained a whole chapter on those Catholics who were shot at dawn. As one Catholic reviewer put it:

34 Bickersteth Diaries, 224.

35 Ibid., 225.

36 Ibid.

37 'A Chaplain', For the Front: Prayers and Considerations for Catholic Soldiers (Market Weighton, 1918), 31-2.

38 See, for example, Fr Benedict Williamson's account of the last hours and execution of Private Patrick Murphy of the Machine Gun Corps on 12 September I91 8 in B. Williamson, 'Happy Days' in France and Flanders with the 47th and 49th Divisions (London, I921), 157-60. 


\section{Army Chaplains and Capital Courts-Martial}

there is one chapter in the Catholic report which is, as the soldier would say, 'a fair knock-out.' That is the chaprer on 'Facing a Death Sentence.' We are not surprised to learn that Catholics, like other people, occasionally ran away or struck their officers (There is no attempt made in the book to show that R.C.'s had any marked superiority in the natural virtues.) But where, outside the Catholic Church, could you find that in every case religion proved the one strong, tranquillizing, consoling force to men about to be shot in cold blood by their own companions. Small wonder that an officer present at one of these scenes ejaculated, 'Good God, yours is the religion to die in. ${ }^{39}$

Whatever personal sympathy chaplains may have evinced for the condemned prisoners to whom they ministered, there is no indication in any of the accounts which have informed this paper that they felt that the system of military justice which condemned them was inherently flawed, notwithstanding the resentment which capital sentences could engender in the army and the recurrent questions which they raised in the House of Commons. ${ }^{40}$ In fact, during the war years, it is very clear that the Churches as a body were uninterested in the justice of executions under the Army Act. In Charles Plater's Catholic Soldiers, executions were of note only in so far as they produced exemplars of the Faith. In David Cairns's Army and Religion report they were ignored altogether. Furthermore, although chaplains readily acted as prisoners' friends, no case has come to light during the course of this research of any chaplain condemning a capital sentence passed by a court-martial.

Indeed, although chaplains freely admitted the unpleasantness of military executions, even in the post-war years there were still those who were prepared to defend them. Notwithstanding the growing public mood of misgiving which led to inquiries by four successive committees in the 1920s and I930s and the drastic curtailment of capital military offences by the Army and Air Force Bills of 1928 and I 930, in 193 I Fr R. H. J. Steuart wrote that, in the case of the military executions of I9I4-I8, one had to think 'soldier-wise' and 'not as a county-court lawyer'. As for Corporal Lewis, whom he had attended back in March 1916, although he had died bravely, Steuart's verdict was that he had simply paid 'the just penalty of his offence'."1

39 The Tablet, 14 February 1920 , 2 ro. Spellings and punctuation as printed.

40 Babington, For the Sake of Example, 82-95, I 75-87.

41 Steuart, March, Kind Comrade, 99, I03. 
The same views appear to have been widely shared in clerical quarters. F. P. Crozier, for example, the officer who played the leading role in the execution of his namesake, Private James Crozier, in February I916, was appalled to find that a clerical friend regarded the whole case as unexceptionable: "Undoubtedly this comes under the heading of "render unto Ceasar", his friend explained, 'It was the law of the land'. ${ }^{42}$ Much to Crozier's chagrin, what most clergy seemed to find objectionable about the circumstances of this execution was that the prisoner was given the opportunity to get drunk beforehand..$^{43}$ In sum, therefore, chaplains' attitudes towards capital courts-martial reflected the general attitudes of their Churches towards capital punishment per se. Moreover, in the context of the chaplains' broader relationship to military authority and their responsiveness to the perceived needs of the time, their attitude towards capital courts-martial was yet another illustration of their general conformity to the military culture in which they found themselves.

University of Birmingham

42 Crozier, The Men I Killed, 228.

43 Ibid., 219. For a further account of the trial and execution of Private James Crozier, see F. P. Crozier, $A$ Brass Hat in No Man's Land (London, I930), $8 \mathrm{I}-4$. 